\title{
The Murderer as Writer, Storyteller and Protagonist: The Case of Krystian Bala
}

\author{
Katarzyna Struzińska ${ }^{1}$
}

Published online: 2 March 2020

(c) The Author(s) 2020

\begin{abstract}
This paper presents the results of the semiotic analysis in which the story of Krystian Bala, a Polish author who was convicted of murder, is studied in detail. The presented case study focuses on the interactions between real and fictional worlds, in particular, on the possibility of amalgamation of a real author's and a fictional storyteller's roles. Furthermore, the double-dimensional analysis of reality and fiction is complemented and broadened by an in-depth examination of how this story has inspired other authors. By discussing real events and texts of culture based on them, this paper aims at presenting the process in which the writer who had turned to be the murderer became the protagonist of artistic creations of others, and, in consequence, a part of a broader socio-cultural phenomenon.
\end{abstract}

Keywords Crime $\cdot$ Popular culture $\cdot$ Works of fiction · Images of crime $\cdot$ Reality and fiction

\section{Introduction}

The close relations between law and literature (or, in a broader sense, law and culture) are unquestionable-for centuries law-related issues have been presented by countless writers who reflected on the motives of crime and the nature of criminals. Despite this ample cultural heritage, the story of Krystian Bala seems to stand out; it raises new questions about the ways in which literature mimics and draws upon reality. Bala is a Polish author who was accused and convicted of murder. His crime would not be extraordinary if not for the fact that during the police investigation against him, some clues gleaned from his novel Amok [1] were brought into play. This particular aspect of the story - an appealing and thought-provoking vision of a work of fiction being a confession to the real-life crime-became an essential focus

Katarzyna Struzińska

katarzyna.struzinska@gmail.com

1 Department of Sociology of Law, Law and Administration Faculty, Jagiellonian University in Kraków, Bracka 12, 31-005 Kraków, Poland 
of the media coverage and caught the attention of the broader public both in Poland and abroad.

The primary purpose of this paper is to present the results of an in-depth case study of the real criminal story and the ways in which it was reproduced and transformed in popular culture. To achieve these goals, a study of various sets of data was essential. The sources used in the analysis mainly consist of media reports on all aspects of this criminal case, the convicted writer's novel Amok, and texts of culture, both literature and films, which refer to the real story. The first phase of the research was focused on close reading and content analysis of relevant available literature for a better understanding of the case. It was aimed at determining the critical facts about the crime, the criminal proceedings, and the perpetrator himself, as well as verifying to what extent the significance attributed to Amok, particularly by the media, was accurate. The results of this analysis were used to establish which elements (signifiers) of the real story seemed to generate the majority of its meaning. These signifiers were used in the second stage of the research-the semiotic analysis of three works of fiction-as reference points for eliciting the meaning of these texts of culture. Firstly, each of them was studied as a separate system of signs which could convey a specific version of Bala's story (synchronic analysis). Secondly, they were compared from the diachronic perspective to examine how the real elements were gradually developed and altered to form new pop-cultural narratives.

This paper is divided into several parts to present numerous detailed findings of the analysis in an accessible way. The two first parts are focused on presenting the original case. The Timeline aims at giving a brief overview of critical events in chronological order. It is intended to serve as a basic framework for different narratives, which are presented in the following sections. The Real events section is an attempt at reconstructing Bala's case in detail, based mainly on media sources. ${ }^{1}$ It presents the police investigation, and the gradual process of discovering subsequent traces, and tries to point out those clues that had some impact on the sensational atmosphere surrounding the case. These elements are precisely the ones that were later used by authors of fictional works, together with the products of their imagination, to re-tell Bala's story.

The next part of the paper is focused on the novel Amok and makes the readers acquainted with its fragments, which have sometimes been treated as an alleged confession to a murder. This part is followed by sections that analyse three texts, one novel and two films, that to different extents refer to Bala's crime and trial. These works of fiction are specific "exhibits" that present the closed crime case in a new light. Although the final judgment has already been delivered, these works propose their own versions of Bala's story and aim at attracting the attention of a continuously growing group of readers and viewers. Consequently, even though the case is not very present in media discourse any more, it is still being delivered to new receivers who often do not know the original case well, and might tend to base their opinions about it on the accounts that have been freely transformed by artists.

\footnotetext{
1 Polish sources, including fragments of the novel Amok written by Bala, cited in this work were translated into English by the author of the paper.
} 


\section{Timeline}

To fully understand how crime, law, literature and culture are related to each other in the presented case study, a more detailed description of the facts is indispensable. The chain of real events started on the 13 th of November $2000,{ }^{2}$ when Dariusz Janiszewski, an entrepreneur from Wrocław (a city in south-western Poland), left his office to meet with a customer and disappeared. Earlier that day, the potential client, who said he was interested in the services of Janiszewski's advertising company, had called and asked to talk to him alone. The caller remained anonymous, and as it turned out later, he had used a public phone located near Janiszewski's office. According to witnesses, when the businessman left for the meeting, he met two individuals waiting for him outside the building. They left the venue together [34].

Almost a month later, on the 10th of December 2000, fishermen discovered the corpse of Dariusz Janiszewski in the Odra river. The victim's body formed a socalled "backward cradle"- a noose around the businessman's neck was connected by rope with his hands tied up behind his back-a position in which "the slightest wiggle would have caused the noose to tighten further" [15].

The autopsy revealed that Janiszewski most probably died because of ligature strangulation; however, owing to some indicators showing that he was still alive when someone dropped him into the river, the possibility of death by drowning was not excluded [34]. Furthermore, the traces left on the deceased's body showed that he had been beaten and starved for several days before he died. The initial investigation brought no outcomes, and in mid-2001, the police closed it due to "an inability to find the perpetrator or perpetrators" [15].

One and a half years later, Jacek Wróblewski, an investigator from the police in Wrocław, conducted a routine review of this unsolved murder case in search of overlooked clues. Wróblewski noticed that a mobile phone Janiszewski had with him on the day of his disappearance had not been found. That was the starting point of a new investigation. The police established the IMEI number of the phone and began to search for this device intensively - it was in use, but by that time it had been sold several times. Investigators managed to find out that the first transaction was made on Allegro, the most prominent Polish auction site, on the 17th of November 2000just 4 days after Janiszewski disappeared. The cell phone was initially sold by a user nicknamed Chris B.7 who turned out to be Krystian Bala-a traveller with an M.A. degree in philosophy, and the author of a novel, Amok (English: amok or amuck), which was published in 2003 [34].

\footnotetext{
${ }^{2}$ Events and other details presented in this part of the paper were primarily reconstructed based on media coverage of the case, in particular: the article by David Graham, True crime. A postmodern murder mystery, published in "The New Yorker" in 2008; the article by Izabela Żbikowska, Akta W. Zbrodnia jak z powieści, skazali za nia pisarza, published in the Wrocław's local edition of "Gazeta Wyborcza" in July 2015; and a documentary Bala: The Novel Killer directed by Russell Eatough and broadcast in 2014 as an episode of the TV series Killers produced by Sky Vision. A paper by Monika Wycykał [33], Gdy Temida pograża się $w$ lekturze... Dziwne przypadki pisarzy-zabójców, served as an important source of information about the case files and other legal aspects connected with this crime.
} 
The police could not interrogate Krystian Bala immediately because since 2001 he had been travelling abroad, e.g. in Asia. To verify if there were any connections between him and Janiszewski, the police checked Bala's background and learned about his blog Amok, where he published fragments of his novel of the same title. This postmodernist book, which became part of the police's investigation, was later described by David Grann as "sadistic, pornographic, and creepy", while its main protagonist, who at the same time narrates the novel, was characterised as "a bored Polish intellectual who, when not musing about philosophy, is drinking and having sex with women" [15].

After reading Amok, which contains a brief description of a murder committed by the main character-Chris — on his lover Mary, the police officers were struck by parallels between the real murderer's modus operandi and the one presented in the work of fiction that did not seem to be coincidental. Investigators thoroughly read the book in the search for clues and hints. The most important similarities between real events and the novel's plot turned out to be a rope used by the murderer; selling crime-related items by auction on the Internet; the motive of jealousy; specific characteristics of Chris from Amok based on characteristics of the author (e.g. alcohol abuse, promiscuity and a fascination with philosophy); events from Bala's life presented in the book as events from Chris's life (e.g. travelling the world; bankruptcy; stealing the statue of St. Anthony from a church; obsession with ex-wife/ex-partner) [13, 15, 33: 534-535]. In consequence of this correspondence, the book was sometimes presented, mainly by media, as "a road map to the crime" (or a "blueprint of the crime") [cf. 13, 15] used by the police in their investigation. Nonetheless, during the criminal proceedings, the novel was rejected by the court and was not treated as evidence of its own.

\section{Real Events}

Krystian Bala became a prime suspect, and police officers investigated the hypothesis that he was responsible for the death of Dariusz Janiszewski. They focused on establishing a set of clues that could verify the plausibility of this assumption. For instance, they discovered that in October 2000, Bala was interested in buying a police handbook on accidental, suicidal and criminal hanging on an auction website [15]. Investigators also asked professional forensic psychologists for the analysis of Amok; they posed questions about similarities between the novel's main protagonist and its author as well as between the fictional and real murders [34]. The experts established that even though Bala and Chris have much in common, they cannot be equated with each other [33: 537]. As forensic psychologists stated: "The perpetrator of Janiszewski's murder is a real person who committed a certain act. Chris is a fictional character created by the author of the book. Comparing a fictional person to a real person is unjustified" [11: 537].

While reconstructing "a logical chain of evidence" to prove that there were connections between Bala and Janiszewski, the police traced a magnetic card used by the person who called the victim on the day of his disappearance. They discovered that this card was used (over 30 times) to call numbers also belonging, for instance, 
to the suspect's office, parents, and girlfriend [15]. Moreover, investigators managed to find out that in 1999 and 2000, Bala faced some troubles in his personal lifehis business went bankrupt; he and his wife Stanisława (diminutive form: Stasia) separated. They established that despite splitting up, Bala could not let his marriage go- - even though he had repeatedly cheated on Stasia, he was still envious of her [13]. Examination of Bala's wife, when she eventually agreed to talk with the police, provided them with information about her brief fling with Janiszewski, of which her husband seemed to be aware. The potential motive of the crime-Bala's jealousy of Stasia-was thus detected [15]. This supposition was reinforced by testimonies of witnesses, who observed how Bala had an angry outburst when he saw his wife talking to another man at a New Year's Eve party in 2000. According to those testimonies, Bala was shouting to the man that he would get rid of him and that he had already done it once "using a rope" [34].

Bala was first arrested and interrogated in September 2005 when he came back to Poland after an extended stay abroad. He claimed that the police kidnapped him, and he accused them of brutal treatment as well as of attempts to force him to confess. In result, an official, in-depth, internal police investigation began. In 2006, the internal control decided that there was "no corroborating evidence" that proved that Bala told the truth [15].

During his first interrogation, and later on, the suspect claimed that he did not know Dariusz Janiszewski and that he had never heard of him. On one isolated occasion, Bala changed his statement and admitted to the prosecutor to killing the victim. Notwithstanding, just after this confession, he interrupted the interview by claiming that he did not feel well. When the questioning started over, he withdrew his confession and refused to sign the affidavit [cf. 13, 34]. Despite that, even without the suspect's confession, witnesses' testimonies, as well as gathered evidence (e.g. materials about Janiszewski and his company gathered on Bala's computer), allowed the police to establish links between him and the victim [34].

On the 22 of February 2007, Bala's case was brought to trial. During the criminal proceedings, the prosecutor's office presented 14 pieces of circumstantial evidence to indicate that the suspect committed the crime. The court of the first instance considered that 10 of them built a logical sequence pointing to the defendant's guilt and refuted his claim of innocence [9]. The court stated that Krystian Bala was guilty of planning and leading the murder, which he had committed with unknown accomplices. Bala was found guilty of luring the victim out of his office, imprisoning him for at least 3 days during which the victim was beaten and starved, as well as binding, stunning and throwing him into the river [34]. On the 5th of September 2007, the defendant was sentenced to 25 years in prison. On the 20th of December 2007, the court of appeal remanded Bala's case - as a result of new court proceedings, the defendant was once again sentenced to 25 years in prison. In May 2009, the court of appeal upheld the second verdict. The defendant's cassation was rejected by the Supreme Court of the Republic of Poland; thus, all the domestic legal remedies were exhausted [cf. 9].

The case and trial of Krystian Bala are presented frequently as the most spectacular in Polish judicial history. Both Polish and foreign media covered the court proceedings. Even an elementary analysis of the press coverage indicates that 
journalists have mainly tended to present this case as a story about a murderer who had killed a man and described his deed in the novel. The story presented by news providers often deviates from real events. A good example here is the text Author jailed for murder he wrote, published on the "Daily Mail" website on the 6th of September 2007. In this article, the unknown authors, who claim that Bala's case was "an intriguing blend of fact and fiction that sent the Polish media into a frenzy", mix the real events with gossip, misunderstandings and figments of their imagination [12]. Firstly, they present Krystian Bala as "a blockbuster author accused of committing the murder he wrote about in one of his thrillers". In reality, he wrote just one book, which was self-published and, as stated by Grann, "by Bala's own estimate (...) sold only a couple of thousand copies" [15]. Secondly, according to the "Daily Mail", the author of Amok described in his book "in detail the brutal murder of a Polish businessman", including such particularities as the victim's corpse being "fished out of a river bearing the harrowing marks of torture"-this presentation of the fictional crime has nothing in common with the murder of Mary depicted in Bala's novel. It seems as if the authors of the article not only did not read Amok but also preferred to focus on sensational rumours rather than verifying facts. Finally, another striking element of this text is a claim that the court found the defendant "guilty of the murder described in his 2003 book". Even though, a few lines below, the journalist quotes a spokesperson of the court who stated that Bala was convicted "for the murder of his ex-wife's lover", the damage is done. The reader is given the sensational but false impression that Bala, if not convicted for a work of fiction itself, was sentenced to 25 years in prison based on the novel he wrote.

Similar narration was also present outside the tabloid media. For instance, on the 9th of August 2007 "The Guardian" published the text Author accused of murder after art imitates death, in which Kate Connolly wrote about Bala being "on trial for murder after writing a crime novel in which he closely detailed the facts of a reallife killing" [10]. On the 6th of September 2007, the brief article Polish author sentenced in slaying published by "The New York Times" stated: "Because his art too closely imitated life — and death—-the Polish novelist Krystian Bala was sentenced yesterday to 25 years in prison (...)" [30]. This tendency is especially noticeable in the titles indicating that Bala's detention and conviction are closely related to his novel, e.g. Crime author charged with murder after the police read his perfect plot [4] and Jail for the author of 'a perfect crime' [5] both published in "The Times" in 2007. Moreover, those media that attempted (with varying degrees of success) to stay true to the real story were more likely to focus on its appalling elements, which could spark readers' interest.

The ways in which this criminal case was shown and commented on by the media were aimed at getting public attention. In an attempt to achieve this goal, the media coverage often focused on the most grisly and mysterious aspects of the story, which were exaggerated and mutated repeatedly. From its very beginning, Bala's case has been surrounded by distortions, which have been further transformed initially by the media and their audience, and subsequently by artists who have referred to this story. Consequently, falsehoods and rumours have been perpetuated, and reaching the truth has become inexpedient, if not almost impossible. The primary source of the extraordinary interest caused by this story seems to be the relationship between 
the work of fiction and real events. Amok has been presented by foreign media continuously, but wrongly, as a famous, ghastly novel. It was called: "a macabre bestselling thriller" [5]; a "bloody bestseller" [4]; "one of his best-selling novels" and a "best-selling blood-thirsty book" [6].

According to the press articles, the court was assigned the task of exploring the "boundaries of fact and fiction" [5], assessing "where reality ends, and fiction begins in the stomach-turning novel" [4]. A significant part of the Polish public following Bala's trial in the media seemed to believe that the novel was crucial evidence-a confession to the crime-which would lead to his conviction [see, e.g., 3, 13, 15]. Therefore, as Monika Wycykał aptly noted, the court "was put in a difficult situation": it had not only to decide, based on gathered pieces of evidence, if Bala committed the crime, but also "it faced the dilemma of how to assess the truthfulness of a work of fiction which, by its very essence, cannot be put to the simple truth test" [33: 538]. The judges needed to decide for themselves "whether a book, a conventional and fictional creation, can be damning against the accused and constitute evidence of guilt in the criminal proceedings" [33: 539]. Ultimately, the court decided that Amok would not be treated as evidence because the parallels between the book and reality were too vague [see: $13,33: 539]$. Nonetheless, this decision did not stop the defendant from using his novel as "a smokescreen" during the trial. Bala consistently informed the media that the case against him was based predominantly on a fictional story. He claimed, for instance, that the police, while interrogating him, "seemed to know the book by heart", and that they "were treating the book as if it was a literal autobiography rather than a piece of fiction" [4]. Bala to this day presents himself as the innocent victim of the oppressive police and justice system and claims that he was convicted just because of his novel.

\section{Amok: A Work of Fiction or a Confession to Crime?}

Amok [1] by its form is a post-modernist novel which has a non-linear plot and can be read in any order. Besides this, the book contains a plethora of word games, metaphors and rhetorical devices, which often make it difficult to understand. Nevertheless, the amount of vulgar language, misogyny, perversion and obscenity included in the novel can surprise a reader even more than its atypical structure.

Amok shows specific philosophical preferences and emphasises that the idea of truth is just an illusion: the place of truth in the modern world has been taken over by narrative. The main protagonist and narrator-Chris-bears a clear resemblance to Raskolnikov, the hero of Fyodor Dostoyevsky's Crime and Punishment. Both Chris and Raskolnikov murder an innocent person; however, while Dostoyevsky's protagonist cannot stand the guilt, eventually confesses his deed and is punished for it, Chris decides to "wear" what he calls "white gloves of silence" and gets away with his crime. According to Grann, "if Raskolnikov is a Frankenstein's monster of modernity", then Chris should be considered "a monster of postmodernity" [15].

In contrast to how the media described Amok and how the public prefers to perceive it, the fictional murder has not much in common with the real events. On the one hand, indeed, the main protagonist of the novel shares many features 
with Bala. Even his name-Chris_is connected with real life: "Chris" might be used as a diminutive form of the name Christian, which is the English version of Polish name Krystian; furthermore, "Chris" is also an Internet nickname used by Bala. On the other hand, the protagonist of the novel kills a woman (Mary), not a man, and his modus operandi differs significantly from the circumstances of Dariusz Janiszewski's death. The fictional character describes his deed as follows:

I pulled out a knife and a rope from under the bed, as you do with a picture story for children to lull them with some nonsense about kingdoms far, far away. I began to unwind the plot of the rope and to make it more interesting, and I was tying a noose. It took me two million years, during which I could think about sixty thousand scenarios of the crime. The cigarette burned my lips. Then I threw a noose around her neck. Mary came to her senses, but she was sure that it was one of those little games that we sometimes performed to spice up the fuck. [...] I tightened the noose with all my strength. Holding the kicking Mary down with one hand, with the other I stabbed the knife above her left breast [...]. The ribs screeched, but the long steel blade entered her. Blood spurted. It ran down her nipples and stomach. It blushed her pubic hair, her thighs. Everything was already splashed with blood. Without the slightest rustle. Without a moan. Without words. In total silence. A sentence of convulsions as during orgasm [1: 56-57].

Mary is thus strangled and stabbed to death, and only the use of the rope constitutes a distant resemblance between the novel and the real crime.

Later in the same chapter, Chris describes how he gets rid of the murder weapons, and informs the reader that he has decided to remain silent about his deed:

I go out to the streets of Paris in white gloves. I smile at people, and I'm as calm as never before. Far, far away, beyond the seven forests, beyond the seven mountains, I abandon the rope cut off from Mary's neck. I sell the Japanese knife on an Internet auction. I pretend that I was a virtual character from a computer game [1: 58].

The remark about selling the knife on the Internet auction is reminiscent of the mobile phone sold by Bala on the online auction platform after Janiszewski's death. Nevertheless, the resemblance is indirect and (again) rather obscure. Consequently, Amok cannot, and should not, be treated as the perpetrator's confession or as a text in which the author incriminates himself. Stanisław Mikke, a Polish lawyer, criticises passing judgments in the media based on "literary evidence", and states that in the book, descriptions of Chris's crime and the emotions it arouses are marginal, and even though the novel might have inspired the police during the investigation, "in inquiries into truth (...) it does not seem to be helpful" [20].

Opinions on the literary quality of the novel are divided. Some readers appreciate its form, the "unique metaphors" used by Bala, and his philosophical reflections (e.g. references to Nietzsche's concept of the Übermensch). Nonetheless, the vast majority perceived Amok, with its hardcore pornography, violence, 
chauvinism, and offensive and scatological language, as graphomania-the feeble attempt of a literary wannabe $[3,20]$. Based on the novel's literary quality, Wycykał states that its author is "a mediocre and inept artist" who became famous only because of the role which his book played in solving the real crime [33: 527]. Correspondingly, Krzysztof Varga, Polish journalist, writer and literary critic, notes that owing to the unprecedented nature of this case, "the greatest world career among Polish writers has been achieved by a hack and murderer" [32].

For the cultural phenomenon that surrounds Amok, it does not seem to be relevant whether it is good or bad literature; what matters are the potential narratives emerging from this piece of literature. This criminal case is alluring to many people, but it seems to be especially fascinating for those who deal professionally with creative activities. Several of them have even decided to (re)tell the story of Krystian Balathe writer-murderer. Nevertheless, as presented below, the truth about Bala, his book and his crime are of little significance for these artists. The re-told stories are not only inconsistent, but they also diverge from one another. Despite having specific things in common, each of them is different in its form, fictional universe (e.g. settings or characters), and content (plot).

\section{Work of Fiction: Exhibit A—Koma (2015)}

Bala's case inspired Aleksander Sowa, a Polish author who self-publishes his works, to write the novel Koma (English: coma) [27]. His book consists mainly of dialogues, which take the form of a journalist's investigation- the journalist, who plays the leading role in the story, writes a story about a convicted murderer who depicted his deed in a novel. He interviews (or at least tries to) all the people who can shed some light on what happened, e.g. the police inspector who solved the case (Wasyl Jagodnikow), the perpetrator himself (Dariusz Laba), his ex-wife (Julia), his lawyer, the wife of the victim, and a detective hired by Laba to follow Julia. Over 215 pages, Sowa carefully reconstructs Bala's case; in particular, he replicates many details of the real killing and of the investigation which followed it.

Nonetheless, the author of Koma also adds some new plot threads, which lead to the point where a broader conspiracy comes to light, and Laba turns out to be innocent and framed for the murder by the police. The journalist rather quickly discovers that, despite the first impression, Laba's case is not as black and white as the media, the police and the court have painted it. Although initially, his article is meant to be a piece about a murderer, it proves to be about a writer and his faith. The new plot threads are products of Sowa's imagination, which is confirmed by a disclaimer at the end of Koma: "The novel is based on facts; however, it interprets them freely and in a literary way, and does not reflect the reality".

Sowa took many details of Bala's case and slightly transformed them. It stands out that he turns some references to the real story into wordplay. While talking about these elements in a short video about his novel, the author points out that an attentive reader should decipher them [28]. The first linguistic riddle is hidden already in the novel's title: Koma is Amok-the title of Bala's book-written backwards. 
Moreover, in the text the states of coma and amok are several times compared to each other and presented as similar; the author notices that the loss of control, not knowing what is going on, and an unusual state of mind are features typical of both of them. This link is presented for the first time when Laba is informing the journalist about his (lack of) alibi for the time of the murder (Laba was alone and drunk at his office, abusing alcohol and mourning his crumbling marriage). The protagonist states that "it was like [running] amok", and then retreats by saying "Yes, an amok... Or maybe a coma." [27: 88]. Later in the same chapter, after the journalist and Laba's conversation about the "conspiracy of the justice system," the narrator concludes that they remain silent because "Words will not change anything. On this side of amok, they are [in] a coma." [27: 90]. Finally, while reading the manuscript of Laba's second book Sekretne życie ślimaków (English: The secret life of snails), the journalist finds a fragment about a certain species of sea snails that spend most of their lives in a coma, but after they wake up, their state rapidly changes and "coma turns into amok" [27: 162].

Furthermore, Sowa also plays with proper nouns. Firstly, he "borrows" the first name of the real victim (Dariusz) and the first name of the real perpetrator (Krystian) and switches them, so that the fictional victim's name is Krystian, while the fictional convicted writer's name is Dariusz. Secondly, the last name of the author of Koma, Laba, is linked with the last name of Krystian Bala: the names La-ba and Ba-la consist of the same syllables written in reverse order. Sowa changes the last name of the victim into "Jankowski"; however, he sometimes accidentally mixes reality and fiction by using the real name "Janiszewski", e.g. in the last sentence of one paragraph the author writes about the victim's family: "After all, the Janiszewski family had a thriving company, so money did not have to be a problem," while the first sentence of the next paragraph states: "And what if (...) husband's death was convenient for Jankowski's wife?" [27: 75]. Thirdly, as Bala decided to call the protagonist of Amok Chris, similarly to the nickname he used himself online, the fictional Dariusz Laba named the main hero of Koma Derek, which can serve as an English version of the Polish name Dariusz (diminutive form: Darek). Besides, Laba's username on the online auction portal he used to sell the victim's cell phone-Derek_L-is constructed similarly to the login used by Krystian Bala-Chris B. Finally, the novel also includes some toponymic references (e.g. the club Szalony Koń [English: crazy horse] appears both in the real case and in its literary version) as well as literary parallels; for instance, Dariusz Laba's wife is called Julia (the Polish translation of the name Juliet), which elicits associations with Shakespeare's tragedy Romeo and Juliet, while in Bala's novel the true love of Chris is called Sonia, and her name refers to Dostoyevsky's Crime and Punishment, in which the love of Sonia helps Rodion Raskolnikov to change and to find redemption from his deed. ${ }^{3}$

Sowa claims that he was not inspired by Amok itself, rather by Bala's case: "all the atmosphere around the author and his book" [28]. Notwithstanding this

\footnotetext{
3 In Koma, Sowa explicitly mentions the novel Crime and Punishment and draws parallels between Dariusz Laba and Raskolnikov. Moreover, he also refers to The Trial by Franz Kafka and to the philosophy of Friedrich Nietzsche.
} 
statement, Amok seems to influence the content of Koma, and indirect links between these two novels, e.g., an analysis of the role "the fatal book" played in convicting a writer, are not the only ones noticeable. In his novel, Sowa reaches for Amok and quotes original fragments Bala wrote about the killing of Mary [cf. 1: 56-58]. Sowa uses them in Koma as parts of the fictional novel (also under the title Koma) written by Dariusz Laba, which helped the police to connect Laba with the murder case [cf. 27: 40-41].

The motive of the book that has an impact on the investigation is one of the key threads in Koma. It allows Sowa to reflect on the essence of literature and the role literature plays in the investigation. "The fatal book" triggers such questions as: Is it a description of the real crime or a work of fiction? Is the writer a murderer or a victim of the imperfect justice system? What is real, and where is the truth? One of the protagonists who attempts to answer these questions is a professor who taught Laba. He believes that the book in question is just provocative wordplay, not a confession, and defends his former student by claiming that, "The fact that incorrect conclusions are drawn upon literary fiction should not be a source of the author's problems" [27: 99].

Sowa decides to use the real events from Krystian Bala's life to equip Dariusz Laba with his specific features. Laba "shares" with the actual convict his character and some episodes from his "pre-investigation" life. The fictional writer is thus an intellectual with an extremely high IQ and a narcissistic personality who wrote the book to become famous. He claims that his controversial novel was supposed to be (and is) extraordinary, original, and like nothing before it. The fictional and real writers present similar views on the role their novel played in the criminal proceedings. Laba compares his situation to the situation of Josef K., the main character of The Trial by Franz Kafka, and claims that he would not be in prison if he had not written this book. He emphasizes that the similarities between his work of fiction and the crime of which he was accused are vague and distant and that they result from the fact that writers often base narratives on their own experiences. In Laba's opinion, his story was deformed by journalists who desired to have a "Polish Hannibal Lecter". Moreover, similarly to Bala, Laba tries to prove his innocence by explaining each clue which led to his arrest as insufficient to prove his guilt (e.g. he emphasizes that he had never signed the affidavit with his confession, so it is of no binding force).

The parallels between Dariusz Laba and Krystian Bala are apparent; nevertheless, the most significant similarities between the real crime and its literary adaptation relate to the circumstances of the murder and the criminal investigation. When it comes to the crime itself, the elements of real events presented in Koma can be divided by topic into several groups:

- The perpetrator's modus operandi, for instance: how the victim was killed (e.g. tying up the noose); the place of finding the corpse.

- The role played by the suspect's book, for example, the fact that it nudges the police investigation in the right direction, but it is not treated as evidence by the court. 
- Events from the writer's pre-investigation life, such as: splitting up with the wife, who moved out with their son; an outburst of jealousy towards the wife during a New Year's Eve party; selling the victim's mobile phone on an online auction; publishing parts of the novel online.

- Investigation: the police's analysis of the book; collecting clues which connect the suspect with the victim and the crime (interest in the police handbook about suicidal and criminal strangling; possession of the victim's pen; calling the victim's office from the public phone); jealousy (revenge) established as the motive of the crime.

- The writer's behaviour during the investigation and court proceedings: the accusation of police brutality; confessing the crime and withdrawing this confession; taking the polygraph test; the claim of being innocent (explaining that the murder described in the novel was meant as a symbol of killing philosophy).

Moreover, Koma shows the extraordinary mass media attraction to the story of the "writer-murderer". Similarly to the real case, the fictional one was covered by the media from all over the world. In the novel, in general, the journalists are presented as responsible for turning the crime and the trial into a media phenomenon, and not paying any attention to the truth. As a good example of how the crime can become a part of popular culture, there is a mention in Koma that Polish film director Roman Polański wants to make a film about Laba. Thus, Sowa, inspired by real media coverage of Bala's case, ${ }^{4}$ seems to interpret the international interest caused by the real crime correctly, and, in a sense, "foresees" that it will soon be made into movies.

Those elements of Koma that Sowa invented should also not be forgotten; they are what makes his novel an original literary text rather than just an ordinary report about a real case. In Koma, the writer convicted with murder turns out to be innocent; the whole case against him is a result of a conspiracy of people in power, and he seems to be a scapegoat of the police and judiciary system. The fictional plot that explains why Laba was convicted points out, for instance: false, dubious or circumstantial pieces of evidence; manipulations of the criminal proceedings corresponding with the changes of law, so that the punishment becomes more severe; witnesses taking back their statements during the trial; the engagement of the Polish counterintelligence agency of internal security; and the fact that even though Laba published his book after the murder of Jankowski, he had started writing it long before this event (when he was still in college). The most striking part of the plot created by Sowa boils down to the existence of another (serial) killer who mimics murders described in Laba's works of fiction. Furthermore, Laba, in exchange for being pardoned, cooperates with the internal security services; he works on a profile of the real perpetrator and helps to catch him. In the final chapters, the reader finds out that the actual murderer is the police inspector, Wasyl Jagodnikow, who was investigating Dariusz Laba.

\footnotetext{
4 According to the press, Roman Polański was indeed interested in making a film based on Bala's case. Nevertheless, this story has never been brought to the screen by this director. See e.g. [8, 22].
} 
The police inspector created by Sowa seems to be a product of the author's imagination and bears little resemblance to the actual investigator, Jacek Wróblewski, who played a leading role in solving the actual murder case. The author of Koma refrained from making references and allusions to the real person, which is justified by the fact that the alternative explanation of the case proposed by him does not reflect the reality. In his conversations with the journalist, the fictional inspector expresses harsh opinions about Dariusz Laba: Wasyl Jagonikow claims that the convicted author is no one; he is just a killer: "Not a philosopher, not a writer, just a murderer, an average murderer. A nit, a creep and a dodger" [27: 63]. He admits that the writer is a brilliant person; nevertheless, in his opinion, Laba is also a mentally sick, manipulative and perverted criminal [27: 5-6 and 63]. Jagodnikow is very critical about Laba's novel as well; according to him, it is not a work of literature but "a pile of crap" (he describes it, inter alia, as "porn," "cheap shit," "sick notes of a psycho," "completely lacking good taste," "a showing-off, not art," and "nothing original"), which is hard to understand, obscene, vulgar and fragmented. Such an approach makes some links between the fictional and the actual crime stories even more visible; in the investigator's words, readers can easily discover an echo of literary critics' real opinions about Bala's Amok.

Finally, it has to be noted that one of the key characters in Koma-the journalist who writes the article about Laba-is completely fictitious. This protagonist's role is to direct the whole story by combining individual threads and presenting them to the readers. His investigation not only creates a general framework for the different points of view and voices of the various actors engaged in the analysed case, but also allows for the cobbling-together of the past events and the introduction of "new pieces of the puzzle", which are eventually blended in one consistent tale. With time and new evidence, the journalist's approach evolves; he is less focused on writing a piece about the writer-murderer and aims at unravelling the true perpetrator of the crime. The journalist manages to achieve his goal; nonetheless, his transformation and his reflections on the concept of truth leave the reader with the idea that truth is elusive (both in the fictional story and in real life) because, as the last paragraph of the novel states, "I do not know what the truth is any more [...]. Because nothing is ever said to the end. Nothing is true. And the truth is nothing" [27: 215].

\section{Work of Fiction: Exhibit B-Amok (2017)}

Krystian Bala also became the hero of the film Amok [24], directed by Katarzyna Adamik, which had its premiere on the 24th of March 2017. This 107-min-long motion picture is not just based on Bala's case; the convicted author sold the rights to his life story to the producers and provided the film-makers with materials for their scenario as well as the permission to use his name, last name and general image. Even though the film is "based on true events", it carries a disclaimer: "All characters, except Krystian Bala, and events depicted in this film are entirely fictitious. Any similarity to actual events or persons, living or dead, is purely coincidental". Such a paradoxical statement seems to be a result of the fact that before Amok 
was finished and came out, the family of Dariusz Janiszewski had opposed it, claiming that the film violated their rights. They believed that even though their relative's first and last names were changed, due to the context, it was still possible to identify him. ${ }^{5}$

As a result of getting the rights to present just one side of the story, the universe of the film Amok could mirror the reality only partially (e.g. features of Bala, events from his life), which compelled the film-makers to change some details. To make sure that characters other than Bala would not be embodiments of real persons engaged in the case, some names were altered. In consequence, the victim is called Mariusz Roszewski; the name of Bala's wife is Zosia (a diminutive form of Polish name Zofia), and the police inspector leading the investigation about Bala is called Jacek Sokolski. Nevertheless, these new names can bring to the mind of a viewer who knows the details of the real case the following associations: the first and last names of the fictional and the real victims sound similar and even rhyme (Mariusz/ Dariusz, Roszewski/Janiszewski), the same goes for the name of Bala's wife (Zosia/ Stasia). Some parallels are also visible in the fictional investigator's name; the scriptwriters kept the first name of the real person (Jacek), and transformed the last name but preserved some link to the reality: the actual investigator's last nameWróblewski-derives from the noun wróbel, which means "a sparrow", while his fictitious counterpart's last name-Sokolski-derives from the noun sokót_-"a falcon".

The plot of the film reconstructs Bala's case in detail; however, it refers not only to the facts established in court but also to the rumours and "legends" (e.g. the belief that Bala included details of the murder in his novel and made it his confession) that in many cases overgrow the verified events. The truth seems once again to be less important than a good story-an appealing narrative that will attract viewers and entertain them. Similarly to Sowa in Koma, the makers of Amok included in the film many well-known details of the investigation and the perpetrator's modus operandi, such as: using the public phone to call the victim on the day of his disappearance; selling the victim's mobile phone on the Allegro platform; the suspect taking and passing the polygraph test; Bala's ex-wife's brief acquaintance with the victim that triggered his suspicions and jealousy, which became the motive for murder; using the media to accuse the police of brutal treatment and attempts to force the suspect to admit to the murder; Bala's confession to the crime given during the interrogation and his later refusal to sign the affidavit. Some of these elements are presented in a new, imaginary context and completed by the fictional threads. For instance, in the film, sometime after Bala's false public accusation of police brutality, Sokolski indeed kidnaps the suspect. He takes Bala to the bank of the Odra river, where he tortures him by recreating the killing of Roszewski (e.g. the inspector ties Bala up in the position of "backward cradle", and holds his head under the water) because he knows that after the false accusation, no one will believe that Bala became the victim of a similar abuse twice.

\footnotetext{
${ }^{5}$ For more about the dispute and the litigation that resulted from it, see e.g. [18, 19, 29].
} 
Also, other elements added by the film-makers often work with the real events or hearsay about the real events, building up and expanding them. The most interesting "concoctions" of this type seem to be:

- Bala being the one who anonymously calls the police 4 years after the crime to inform them that the person who killed Roszewski wrote a novel, Amok, in which they will find all clues necessary to solve the case.

- Portraying Krystian Bala as captivated by the murder of Mariusz Roszewski. His obsession manifests itself in, for example, his visit to the crime scene with his wife and little son; his collecting crime-related pictures and newspaper scraps; and his calling the police to learn about the progress of the investigation.

- Bala's desire to make sure that his ex-wife, Zosia, will hear about the novel and read it as a driving force of his actions.

- A fling between Inspector Sokolski and Zosia during the investigation.

- Bala's claim that the rope is a key to the case.

- Bala's suggestions about the perpetrator being a police officer who believes that he is an "Übermensch" - as he expressed it: "Somewhere on the street is an Übermensch killing everything that moves. A fucked-up cop who hopes to commit a perfect crime". Interestingly, Sowa proposed a similar version as a solution to the fictional crime case; in Koma, the police officer leading the investigation turns out to be the perpetrator.

- The police engaging Bala in their investigation: Jacek Sokolski not only discusses the crime case with him, because, as he claims, "There are rumours that Amok is about Roszewski. Who better to ask than the author?" but also takes him to his summer house to go through case files in search for clues. This motive of the law enforcement looking for Bala's help in finding the murderer (in fact, his help in catching himself), again, bears some resemblance to Koma, in which Laba cooperated with the internal security agency on solving the crime. ${ }^{7}$

One of the most compelling aspects of the film is how it deals with the novel Amok written by the real Krystian Bala. The book is a hero of its own and plays a crucial role in this motion picture, which is not only named after it but, to some extent, seems to be "overshadowed" by it. The novel and references to it keep appearing on the screen; some of its fragments are even transferred to the picture or mixed with

\footnotetext{
${ }^{6}$ Nietzsche's concept of the amoral Übermensch who is allowed to do anything, including killing another person, is an important philosophical reference point for film-makers. It allows them to imply that Bala, due to his smugness and sense of superiority, acts (at least in his opinion) as an Übermensch. This motive occurs, for instance, at the beginning of the film, when during a university philosophy lecture Bala gives the following answer to the professor's question about what Nietzsche meant by saying that "a man is a rope between beast and Übermensch": "In the past, as beasts [animals] we fucked and killed to survive; in the future, as Übermenschen we will do that for pleasure." Furthermore, when Bala accuses Sokolski of brutal treatment, he calls him Übermensch. The inspector responds to this accusation several scenes later, when he tortures Bala on the riverbank, by saying: "Do you feel like an Übermensch? Do you? Because I do".

7 It is difficult to estimate to what extent similarities between Sowa's novel and the film Amok are coincidental.
} 
its plot. The first example can be found as early as the opening scenes, which show how Bala ties up and stabs a woman, which, in a way, inserts the murder of Mary described in the actual book into the movie. Only after his wife calls him for dinner do viewers learn that all they have just seen was a representation of the protagonist's thinking processes while he was writing his novel. Another thought-provoking manifestation of blending the scenario and the real-life novel is a party thrown by Bala's friend, Froggy. When the main protagonist falsely assumes that the police have appeared at the party, he is sure that they are coming after him, and it almost leads him to suicide. The real Bala described a similar event in Amok as something that happens to Chris after he kills Mary. In this case, the film-makers thus decided to present a scene from literary fiction written by the author about whom they made a film as an event from the life of the film character. In consequence, viewers have to deal not only with a mixture of reality and fiction but also with an unusual compound of reality and two different fictional stories.

In the film, Bala's novel is essential both for the author himself and for the police investigator who tries to solve the cold case. The fictional Krystian Bala pursues three things: glory, fame and wealth. To achieve those goals, he tries to gain as much publicity for his novel as possible. The protagonist is aware that he became famous because of the relationship between the real-life crime case and his work of fiction. He aims at increasing the sales of the book and getting it translated into foreign languages; consequently, he hesitates to take actions (e.g. taking the polygraph test) which, according to him, will prove his innocence and make the book less popular among readers.

Even though Bala builds his literary career on the controversies surrounding Amok, he still tries to convince other people that the allegations against him are false: that he is an author, not a murderer. He claims that he has created a new literary genre, a "post-modern crime mystery" which comprises "a situation in which the author gets accused of deeds that have so far been nothing but fiction". On the other hand, such public statements do not stop him from taking an opposite position in his relations with Jacek Sokolski. Bala's behaviour confirms the police inspector's suspicions that Chris from the novel is, in fact, an alter ego of the author. The writer's confession, made during the interrogation and later withdrawn, can serve as a good example of Bala's attitude towards the book as well as an argument justifying the thesis of Chris being his "doppelgänger". While admitting that he killed Roszewski, Bala refers directly to Amok and the "white gloves of silence" worn by Chris to deal with his guilt by saying: "I've taken mine [white gloves] off, see?! They're off. They're off! I confess. I am the one who killed Roszewski”.

Jacek Sokolski, the primary opponent of Bala, has a significantly different approach towards Amok - for him, the novel is not a magnum opus of any kind; he describes it as "pure evil" that should be avoided by readers. Moreover, from the very beginning, the investigator believes that the book is something more than just a false lead. He is convinced that Bala described the murder in the novel because he felt guilty and wanted the world to learn about his crime. Consequently, Sokolski treats the novel as a "written confession with his [Bala's] name on it". The inspector is increasingly consumed by Amok. As described by his boss, in search of evidence, Sokolski turns his police subordinates into a "book club" by making them read 
Amok and look for parallels with the real people. Eventually, Sokolski's conjectures are confirmed by Zosia, who informs him that while writing the novel, Bala told her that he was using simulacra of the real people with changed names. As a result, the fragments of the book that refer to Chris's use of rope and knife to kill Mary are read in the court and treated as Bala's paraphrase of the murder committed by him in real life. Nonetheless, the inspector's obsession with Amok does not end after the writer's conviction; he sends a letter to the imprisoned Bala and promises to make sure that he will not commit another crime. Sokolski pledges to be the most dedicated and attentive reader of any story that the convict might publish in the future. Such an attitude proves that the tense game between the suspect and the investigator, which has been developing throughout the entire film, is not over and most likely will last until the end of their days.

Like the novels Amok by Krystian Bala and Koma by Aleksander Sowa, the film Amok poses questions about the essence of truth. This embellished adaptation of the real story does not deviate from the approach to the truth, as not existing or impossible to establish, which has been present in the other texts of culture inspired by Bala's case. The main protagonist of the film expresses this idea when he discusses with his lawyer the polygraph test that could prove his innocence. When the lawyer informs Bala that telling the truth is the only way to pass such a test, the writer asks whose truth he should tell-his own or "theirs". In this scene, viewers are confronted with the concept of multiple truths that depend on the context and the speaker's conviction as well as on the listener's ability to accept something to be true. In Amok, the film-makers show Bala's case, but they neither judge their protagonist nor make any peremptory statements about what happened. They propose one version of the story and allow spectators to interpret events, as well as to decide what they will treat as the truth, on their own.

\section{Work of Fiction: Exhibit C-True Crimes (2016)}

The final subject of analysis in this paper is the film True Crimes (also known by the title Dark Crimes) [7] directed by Alexandros Avranas. This work of fiction deviates from reality to the greatest extent. The story of Krystian Bala inspires the 92-minlong production, but the film is only a loose adaptation of the real events. Chosen aspects of the actual case were treated here merely as a general framework that the film-makers filled with new content. They added many elements, for instance, the illegal sex industry (the vital role of the sex club "The Cage"); conspiracy within the police forces; insights from the life of Tadeusz Pietrzak (Tadek), the police inspector leading the case (e.g. his family life, problems at work and attempts to regain his former position). The new threads attached to the story make the film darker, more sadistic and more obscene; it contains much violence and sexual abuse. In the very first scenes, viewers see a sexual orgy in "The Cage". This venue seems to symbolise all evil, which is illustrated by the quote from the novel Alicja by Krystof Kozlov, the fictional author accused of murder, in which he describes the sex club mimicking "The Cage" as follows: "Marek understood that there were no rules in the sex club. If you wanted to beat a naked girl, you could beat her; you could hang 
her from the ceiling. Really, nothing was too much trouble as long as he didn't kill the girls" [7].

Like the aforementioned works of fiction, the film True Crimes also makes some allusions to details of the real story; however, in this case, they are more indirect. Firstly, the counterpart of Krystian Bala is Krystof Kozlov, the author of "perverted books" and the main suspect in the investigation into the murder of Daniel Sadowski. Moreover, Kozlov's first name seems to be a contaminated version of a Polish name, Krzysztof, that translates into English as Christopher and can be shortened to "Chris"- the name of the main protagonist of Bala's novel. Secondly, the last name of Kozlov derives from the Polish noun koziot, which means "goat"; it seems to be a reference to the goat, a symbol of evil, which was depicted on the original cover of Amok. Finally, both Kozlov and Bala have in their lives women of significance; Kozlov has a girlfriend Kasia, a prostitute, working in "The Cage" seems. The main female protagonist of this film seems to be, once again, an analogue to Sonia from Crime and Punishment by Dostoyevsky. ${ }^{8}$

More in-depth analysis of True Crimes suggests that the film-makers used only selected elements of the actual criminal case, and referred to it in a rather general way. The following aspects of the real story found their way into the scenario:

- The role of a single police investigator who tries to solve an old murder case;

- The way the victim was murdered;

- The novel serving as a source of clues which help to solve the case;

- Sharing the book on the Internet;

- Some role played by the writer's significant other in solving the case;

- The alleged perpetrator's claims of innocence, and emphasis continually put by him on the fact that his book is not reality but fiction;

- The suspect taking a polygraph test;

- The writer's accusation of brutal and humiliating treatment by the investigator; nevertheless, in the film, those accusations turn out not only to be false but to be directly quoted from Kozlov's novel;

- Jealousy being a motive to act; however, in the film, the person driven by jealousy is not the author, but the police officer, who tries to solve the case to prove the wrongdoings of the "dirty" chief of police (e.g. his engagement in the illegal sex industry).

In True Crimes, many additional elements, which deviate from the real story, were added. The most striking differences seem to be the ones related to the victim, Daniel Sadowski. Firstly, in contrast to the actual events, in the film, Kozlov admits from the beginning that he and Sadowski knew each other-they were neighbours, even friends, and they both visited "The Cage". Secondly, as the viewer learns with time, the real sadist in the plot is not the writer who allegedly committed the murder

\footnotetext{
8 To highlight parallels between the film plot and Dostoyevsky's novel, Crime and Punishment is directly mentioned in the motion picture: viewers can see the police inspector finding it among Kozlov's books.
} 
but the victim-Sadowski many times brutally sexually abused Kasia, a prostitute and drug addict who worked in the club, and the love interest of Kozlov. The story of Kasia is used by Kozlov when he writes the novel Alicja, which contains some details of the killing of Sadowski.

When Tadek, the police inspector, tries once again to solve the cold case, the novel draws his attention because it includes details that could only be known by the murderer and the police. In consequence, he goes after Kozlov, and, eventually, as a result of some plot twists (e.g., police planting evidence in the house of the writer's parents, a brief affair between Kasia and Tadek, the closing of the case against Kozlov), he gathers enough clues to arrest him. Kozlov, who in fact could not have committed the crime because, at the time of the murder, he was out of the country, decides to take the blame in an attempt to protect Kasia. Only in the final scenes Tadek meet Kasia and persuade her to tell him the truth. The prostitute confesses that she was the one who killed Sadowski-one time when he visited her at the club and forced sadistic intercourse on her, she did not finish the sexual "choking game" at the right moment and let him suffocate. She claims that she did it to protect the "only family" she had-her daughter and Kozlov. In the final scenes, to prevent the truth from coming out, Kasia kills the inspector by giving him a poisoned drink.

Like Amok directed by Adamik, the film True Crimes is focused on a specific psychological game between the investigator and the suspect. On the one side, there is an arrogant, egoistic, and even slightly diabolical but still very intelligent author who represents a post-modernist way of thinking and writes "clinically naturalistic", sadistic books that are full of violence (especially against women). ${ }^{9}$ On the other is Tadek - the actual main protagonist - a degraded police inspector who is obsessed with the unsolved murder case because of which he lost his previous position.

The novel Alicja significantly influences the psychological game between Tadek and Kozlov. For the inspector, investigating the book often seems to be more critical than scrutinising the suspect. As in the other works of fiction inspired by Bala's story, once again, the investigator in True Crimes is hugely focused on the content of the novel; he reads it and listens to it many times, as well as knowing large fragments by heart. While interrogating Kozlov, Tadek even claims that the book is the author's confession, because the resemblance between the murder described in it and the killing of Sadowski is too significant to be only coincidental. As he puts it: "Your novel. Same victim, same location, same means of death. Only the police officer and the killer could know these facts. The details of the murder were never published, so how do you know that?".

It should be emphasised that the fictional novel does not imitate Amok by Krystian Bala-it has a different plot that focuses predominantly on the sex club. The main similarity between these two books is the fact that they are both written from the perspective of narrators who are decadent writers. Also, the function Alicja has in solving the investigation bears a resemblance to the role which Amok played in the true-crime story. Nonetheless, the novel and the cold case depicted in the film

\footnotetext{
9 Such a depiction of Kozlov seems to have much in common with the way in which the behaviour and convictions of Krystian Bala have been presented in the media.
} 
have more in common than in real life; the film-makers made similarities between the two more frequent and explicit. For instance, the detailed description of how the victim was strangled presented in Alicja matches the particularities of the fictional murder of Sadowski. Interestingly, it also refers to some details of the real Krystian Bala's modus operandi.

One of the most evident parallels between the film and Bala's novel is a plethora of reflections about the nature of good and evil, and even more importantly about the concept of truth, which is treated here as an intellectual construct-something that does not exist in the real world. Such an approach is presented, for instance, by Krystof Kozlov, who openly states that the only idea that matters is "nothing is real," and that people are the ones who create both facts and fiction. When one of Kozlov's readers asks him what truth is for him, he expresses this thought in a more detailed and slightly deceitful way by saying: "Truth cannot be separated from us; it cannot exist independently of the human mind. Truth is strong and will prevail. There is nothing wrong with that, except it is not true. Truth is what you make it. Reality is perception".

Furthermore, Kozlov tends to avoid responsibility for what he writes, and steadily repeats that his works are just something he writes, not something he says, thinks or means, so they cannot be treated as reflecting facts. For him, every deed after being done loses its factual essence and becomes just another story. Kozlov explains this thesis with an example of murder: "You murdered a man. And the moment is done; you already re-tell the story to yourself. So the act of killing is not your act of killing but belongs instead to some fictional simulacrum".

Tadek's chief represents a similar view on truth. He ignores the fact that the wrong man was charged for murder because what had been established as real is not only more convenient but also brought him a promotion. This protagonist says that he does not care about the truth because Kozlov being a murderer "is the story now". He expresses the idea of reality being nothing more than just a narrative by stating: "People do not want justice. They want good and evil. Big bright stories told with conviction. That's what we do. That's what you did [in Kozlov's case]. You wrote big bright stories told with conviction. Well done". Even though this assertion is unfolded just at the end of True Crimes, the idea itself permeates the whole picture. The police inspector's chase after the truth is doomed to failure; every time he finds out what seems to be the truth, the real events turn out to be different from the established "facts". In the film, the truth never triumphs-even when the main character finally learns the truth about what happened, he must pay for this knowledge with his life. Instead, the narratives, dependent on the context and particular interests, prevail.

\section{Conclusions}

The case of Krystian Bala has made many people reflect on the possibility of an actual crime being transferred into a fictional novel by the writer, who at the same time is the perpetrator. It fits the description of popular criminal trials given by Walter L. Hixson in his analysis of four sensational American crime cases: 
similarly to them, it has "the features that captivate the public: drama, narrative, rhetoric, and advocacy" [16]. Such criminal trials appeal to "the natural human fascination with mystery and evil that lies at the core of public interest in murder narratives," and are extensively covered by the media [16]. That results in the creation of the "carnival atmosphere" around them and in changing them into "larger public dramas" [16]. Such crime stories often secure their places in broadly understood culture and are reproduced in different forms. We can observe this process of re-telling in Bala's case. Owing to the extent in which it has resonated with popular culture, it can be argued that it is an example of crime being both "a negative phenomenon" as well as "a cultural resource, one into which everyone dips for ideas about crime and justice" [25: ix]. Like some other famous criminal cases, this one also becomes an "image event", a spectacle, that might be reproduced globally [31: 1-3] and can be "overwhelmingly present" in popular culture [25: 3].

The presented case study aims at applying the semiotic analysis to this particular "image event". It shows that Bala's story and texts inspired by it are semantic structures of open character, which refer not only to the real events but also to each other. Interactions between them are non-linear, and they seem to "incorporate various significant elements that change the original meaning in the context of a new whole" [21: 305]. Their distinguishing feature is a continuous transformation of some common elements, which results in producing new meanings.

Works of fiction presented as exhibits in this paper seem to match what Yuri Lotman wrote about the modelling of an artistic object-they show how differently the original narrative (pattern) can be transformed [21: 288]. When real case is processed, its aspects are partially reduced-some of them are omitted, altered or supplemented, while others change their character and become signs of the narrative's field [cf. 21: 288-289]. Therefore, it is not surprising that the presented study proves that the use of the same elements of the actual story (signifiers) by different authors does not generate identical meanings in their works; they create new systems of signs [cf. 21: 288-289].

In the case of literature, derivative texts can be perceived as secondary modelling systems because "artistic operations lead to a change in designation so that, as a result, the world denoted by each other differs from what is treated as its prototype" [21]: 292]. This is also the case with other texts of culture: rather than copying reality, they construct their own "models of the world of denotations," in which some original meanings change, and new ones are produced [21: 292-293]. A good illustration of this process in this case study is Bala's novel Amok, which, on the one hand, is believed to denote certain real events, and, on the other, becomes the object of denoting (this is most evident in the novel Koma).

The artistic license not only allows the analysed texts to model the actual story, but also opens them to various points of view [21: 289]. Ultimately, the perception of their recipients is what will decide if and how the signifiers and signified elements contained therein are understood [cf. 21: 299]. Since these understandings are considerably individual, one cannot exclude a reading of texts inspired by this story in which the texts would be completely detached from their original context. In such cases, those texts can become more important than the real events, and the 
hyperreality within them will replace the reality which they were supposed to emulate [cf. 2: 20-21].

As it follows from the analysis of Bala's story and its media and artistic representations, a crime restated in popular culture becomes blurrier, recedes from facts, and often turns into a different story. Moreover, these new narratives constructed around the crime can shape the public's opinion not only about this particular case but also about crime in general. Nicole Rafter and Michelle Brown aptly noted that representations of crimes in popular culture have a crucial impact on the ways in which the majority of people think about criminal justice, because "[w]e were not born with opinions on these matters; rather, we build up (and change) our opinions over time in light of cultural encounters" [25: 186]. This is especially relevant for crime films because they present the public with multidimensional (and often unconventional) images of crime - they "enable us to follow crime incidents or criminals through time and space" and to better understand how "values and emotional contexts" shape criminal behaviours [25: 185 and 5].

Bala's case might be one of the first stories that drew global attention to such a possibility of crossing the border between facts and fiction; nevertheless, this case of a writer-murder is not one-of-a-kind. For instance, in 2018 world media extensively covered the story of Nancy Crampton-Brophy, an American romance novelist, author of the novel The Wrong Husband and the essay How to Murder Your Husband, who was accused of killing her spouse, and in 2017 there was similar coverage of the case of Liu Yongbiao, a Chinese author (e.g., of the novel The Guilty Secret), who was sentenced to death for murdering four people after a 20-year-old cold case was solved [cf. 14, 17, 23, 26]. Crime stories of authors imitating real-life crimes in their works are open to many interpretations; therefore, they raise questions about the nature of truth and the borders between facts and fiction. It seems justified to expect that in the future a broader theorization and in-depth analysis of similar cases will be conducted by researchers representing various disciplines-from the semiotics of law to criminology, and from cultural studies to ethics.

Open Access This article is licensed under a Creative Commons Attribution 4.0 International License, which permits use, sharing, adaptation, distribution and reproduction in any medium or format, as long as you give appropriate credit to the original author(s) and the source, provide a link to the Creative Commons licence, and indicate if changes were made. The images or other third party material in this article are included in the article's Creative Commons licence, unless indicated otherwise in a credit line to the material. If material is not included in the article's Creative Commons licence and your intended use is not permitted by statutory regulation or exceeds the permitted use, you will need to obtain permission directly from the copyright holder. To view a copy of this licence, visit http://creativecommons.org/licen ses/by/4.0/.

\section{References}

1. Bala, Krystian. 2003. Amok. Wrocław: Croma.

2. Berger, Arthur Asa. 2018. Semiotic analysis. In Media analysis techniques, ed. Arthur Asa Berger, 3-52. London: Sage Publishing. 
3. Bereś, Stanisław. 2007. Amok, czyli gra w autodenuncjację. Gazeta Wyborcza. http://wyborcza. pl/1,75410,4466223.html. Accessed 23 Jan 2020.

4. Boyes, Roger. 2007a. Crime author charged with murder after the police read his perfect plot. The Times (United Kingdom) Sep 08, 2007: 31.

5. Boyes, Roger. 2007b. Jail for author of 'a perfect crime'. The Times (United Kingdom) June 09, 2007: 37 .

6. Charles, Miranda. 2007. 25 years jail for murder he wrote. Herald Sun (Melbourne) June 09, 2007: 035 .

7. Cheng, John, David Gerson, Simon Horsman, Brett Ratner, Jeffrey Soros (Producers), and Alexandros Avranas (Director). 2016. True crimes [Motion picture]. Poland, United States \& United Kingdom: InterTitle Films, Polski Instytut Sztuki Filmowej and RatPac Entertainment.

8. Child, Ben. 2011. Polanski linked with film version of Polish author murder case. The Guardian. https://www.theguardian.com/film/2011/apr/11/roman-polanski-krystian-bala-film. Accessed 23 Jan 2020.

9. Cichowski, Jacek. 2017. Krystian Bala, mój przyjaciel morderca?! Reporter w celi autora książki Amok. Gazeta Wyborcza: Duży Format. http://wyborcza.pl/duzyformat/7,127290,21799743,kryst ian-bala-moj-przyjaciel-morderca-reporter-w-celi.html. Accessed 23 Jan 2020.

10. Connolly, Kate. 2007. Author accused of murder after art imitates death. The Guardian. https:// www.theguardian.com/world/2007/aug/09/books.booksnews. Accessed 23 Jan 2020.

11. Court files in the Krystian Bala's trial, cards 6105 and 6106, as cited in Wycykał, op. cit.

12. Daily Mail. 2007. Author jailed for murder he wrote. Mail Online. https://www.dailymail.co.uk/ news/article-480080/Author-jailed-murder-wrote.html. Accessed 23 Jan 2020.

13. Eatough, Russell. 2014. Bala: The novel killer [Television series episode]. In Killers: Behind the myth, ed. Tom Adams. Sky Vision: Isleworth.

14. Fieldstadt, Elisha. 2018. Romance novelist Nancy Crampton-Brophy pleads not guilty to murdering husband. NBC News. https://www.nbcnews.com/news/us-news/romance-novelist-nancy-cramptonbrophy-pleads-not-guilty-murdering-husband-n910356. Accessed 23 Jan 2020.

15. Grann, David. 2008. True crime: A postmodern murder mystery. The New Yorker. https://www. newyorker.com/magazine/2008/02/11/true-crime. Accessed 23 Jan 2020.

16. Hixson, Walter L. 2001. Murder culture and injustice. Kindle ed. Akron: University of Akron Press.

17. Hoyle, Ben. 2018. Nancy Crampton-Brophy: Police arrest writer of tips on killing your husband. The Times. https://www.thetimes.co.uk/article/whodunnit-police-arrest-writer-of-tips-on-killingyour-husband-2b579dx76. Accessed 23 Jan 2020.

18. Karbowiak, Michał and JS. 2017. Sąd zakazuje twórcom Amoku ujawniania danych ofiary. Kina zaczynają wycofywać zwiastun. Gazeta Wyborcza: Wrocław. http://wroclaw.wyborcza.pl/wrocl aw/7,35771,21423391,sad-zakazuje-tworcom-amoku-ujawniania-danych-ofiary-kina.html. Accessed 23 Jan 2020.

19. Karbowiak, Michał. 2017. Spór o Amok rozstrzygnie sąd. Gazeta Wyborcza: Wrocław. http://wrocl aw.wyborcza.pl/wroclaw/7,35750,21583241,bedzie-odszkodowanie-dla-rodziny-zamordowanegoza-film-amok.html. Accessed 23 Jan 2020.

20. Mikke, Stanisław. 2007. Literackie dowody. Palestra 9-10: 170-175.

21. Mitosek, Zofia, ed. 2012. Semiotyka. In Teorie badań literackich, 278-311. Warszawa: Wydawnictwo Naukowe PWN.

22. Newsweek. 2013. Christoph Waltz zagra polskiego policjanta. W filmie Romana Polańskiego. Newsweek Polska. https://www.newsweek.pl/the-crime-christoph-waltz-roman-polanski-wroclaw-newsw eekpl/r38pckp. Accessed 23 Jan 2020.

23. Phillips, Tom. 2017. The guilty secret: Chinese crime writer arrested for four cold-case murders. The Guardian. https://www.theguardian.com/world/2017/aug/16/guilty-secret-chinese-writer-arres ted-cold-case-murders. Accessed 23 Jan 2020.

24. Pisula, Beata, and Kasia Adamik. 2017. Amok [Motion picture]. Warsaw: K\&K Selekt and Polski Instytut Sztuki Filmowej.

25. Rafter, Nicole, and Michelle Brown. 2011. Criminology goes to the movies. Crime theory and popular culture. New York: New York University Press.

26. Salo, Jackie. 2018. Crime author sentenced for murders that inspired his novels. New York Post. https://nypost.com/2018/07/31/crime-author-sentenced-for-murders-that-inspired-his-novels/. Accessed 23 Jan 2020.

27. Sowa, Aleksander. 2015. Koma. Opole: Aleksander Sowa Self-Publishing. 
28. Sowa, Aleksander. 2017. Sprawa powieści “Amok” (Krystian Bala). Aleksander Sowa o ksiażce "Koma" [Video file]. Retrieved from https://www.youtube.com/watch?v=I-5UjCiSZHs. Accessed 23 Jan 2020.

29. Szczerba, Jacek. 2017. Amok wokół Amoku Kasi Adamik. Protesty rodziny ofiary mordercy, który jest bohaterem filmu. Gazeta Wyborcza. http://wyborcza.pl/7,101707,21387970,amok-wokol-amoku -kasi-adamik-protesty-rodziny-ofiary-mordercy.html. Accessed 23 Jan 2020.

30. The New York Times. 2007. Polish author sentenced in slaying. The New York Times. https://www. nytimes.com/2007/09/06/books/06arts-POLISHAUTHOR_BRF.html. Accessed 23 Jan 2020.

31. Valier, Claire. 2003. Crime and punishment in contemporary culture. London: Routledge.

32. Varga, Krzysztof. 2017. Amok. Pisarze to kabotyni, czyli grafoman morderca. Gazeta Wyborcza: Duży Format. http://wyborcza.pl/duzyformat/7,127290,21601359,amok-pisarze-to-kabotyni-czyli -grafoman-morderca-varga.html. Accessed 23 Jan 2020.

33. Wycykał, Monika. 2013. Gdy Temida pogrąża się w lekturze... Dziwne przypadki pisarzy zabójców. In Literatura $w$ granicach prawa/XIX-XX w./, ed. Kamila Budrowska, Elżbieta Dąbrowicz, and Marcin Lula, 517-540. Warszawa: Instytut Badań Literackich PAN Wydawnictwo.

34. Żbikowska, Izabela. 2015. Akta W. Zbrodnia jak z powieści, skazali za nią pisarza. Gazeta Wyborcza: Wroctaw. http://wroclaw.wyborcza.pl/wroclaw/1,35771,18277385,Akta_W_Zbrodnia_ jak_z_powiesci_skazali_za_nia_pisarza.html?disableRedirects=true. Accessed 23 January 2020.

Publisher's Note Springer Nature remains neutral with regard to jurisdictional claims in published maps and institutional affiliations. 